\title{
Influence of sodium hypochlorite and EDTA on the microtensile bond strength of a self-etching adhesive system
}

\author{
Doglas CECCHIN ${ }^{1}$, Ana Paula FARINA ${ }^{2}$, Daniel GALAFASSI ${ }^{3}$, João Vicente Baroni BARBIZAM ${ }^{4,5}$, \\ Silmara Aparecida Milori CORONA ${ }^{6}$, Bruno CARLINI-JÚNIOR ${ }^{4}$
}

\author{
1- DDS, Graduate student, Endodontic Division, Department of Restorative Dentistry, Piracicaba Dental School, State University of Campinas, Piracicaba, \\ SP, Brazil. \\ 2- DDS, Graduate student, Prosthodontics Division, Department of Restorative Dentistry, Piracicaba Dental School, State University of Campinas, Piracicaba, \\ SP, Brazil. \\ 3- DDS, Graduate student, Department of Restorative Dentistry, Ribeirão Preto Dental School University of São Paulo, Ribeirão Preto, SP, Brazil. \\ 4- DDS, MS, PhD, Assistant Professor, Department of Restorative Dentistry, Dental School, University of Passo Fundo, Passo Fundo, RS, Brazil. \\ 5- Visiting Assistant Faculty, School of Dentistry University of California Los Angeles, CA, USA. \\ 6- DDS, MS, PhD, Associate Professor, Department of Restorative Dentistry, Dental School, University of São Paulo, Ribeirão Preto, SP, Brazil.
}

Corresponding address: Doglas Cecchin - Departamento de Odontologia Restauradora - Faculdade de Odontologia de Piracicaba - UNICAMP - Av. Limeira 901 - Caixa Postal 52 - 13414-903 - Piracicaba, SP - Brasil - Fone: +55-19 21065250 - Fax: +55-19-2106-5251 - e-mail: dgscecchin@yahoo.com.br

Received: February 19, 2009 - Modification: September 06, 2009 - Accepted: September 21, 2009

\section{ABSTRACT}

\begin{abstract}
Chemical substances used during biomechanical preparation of root canals can alter the composition of dentin surface and affect the interaction with restorative materials. Objective: The purpose of this study was to evaluate the microtensile bond strength $(\mu \mathrm{TBS})$ of a self-etching adhesive system to dentin irrigated with sodium hypochlorite $(\mathrm{NaOCl})$ and ethylenediaminetetraacetic acid (EDTA). Material and Methods: Thirty human third molars were sectioned $3 \mathrm{~mm}$ below the occlusal surface, polished with 600- to 1200-grit silicon carbide papers, and randomly divided into 3 groups: G1 (control): no irrigating solution; G2: $1 \% \mathrm{NaOCl}$; and G3: $1 \% \mathrm{NaOCl}$ followed by the application of $17 \%$ EDTA. The specimens received the self-etching adhesive system (XENO III - Dentsply), restored with microhybrid composite resin (Z250 - 3M ESPE), sectioned and trimmed to create 4 hourglass-shaped slabs of each tooth. The slabs were tested in microtensile strength in a universal testing machine (Emic DL 2000) at a crosshead speed of $0.5 \mathrm{~mm} / \mathrm{min}$ until fracture. The results were analyzed statistically by ANOVA and Newman-Keuls test. Results: Mean $\mu$ TBS values and standard deviations in MPa were: $\mathrm{G} 1=11.89 \pm 4.22 ; \mathrm{G} 2=19.41 \pm 5.32$; $\mathrm{G} 3=11.34 \pm 4.73 .1 \% \mathrm{NaOCl}$ increased the adhesive resistance significantly $(p<0.001 /$ $\mathrm{F}=22.5763$ ). The application of $1 \% \mathrm{NaOCl} / 17 \%$ EDTA resulted in statistically similar $\mu$ TBS to the control group. Conclusions: None of the irrigants affected negatively the $\mu$ TBS of XENO III to dentin. The use of $1 \% \mathrm{NaOCl}$ alone resulted in higher bond strength than the other treatments. The combination of $1 \% \mathrm{NaOCl}$ and $17 \%$ EDTA produced similar bond strength to that of untreated dentin.
\end{abstract}

Key words: Dentin-bonding agents. EDTA. Sodium hypochlorite.

\section{INTRODUCTION}

Effective cleaning and shaping of root canals and adequate apical seal are essential to the success of endodontic treatment ${ }^{33}$, and the appropriate restoration of devitalized teeth is fundamental to prevent bacterial infiltration ${ }^{3,12}$. In addition, the purpose of restoring endodontically treated teeth is to reestablish their functionality and esthetics, and avoid fracture of the remaining dental structure ${ }^{1}$. Vire $^{31}$ (1991) verified that $59.4 \%$ of the failures in root-filled teeth occur during re-establishment of the lost dental structure.

Chemical substances used during biomechanical preparation of root canals can alter the composition of dentin surface and affect the interaction with restorative materials $s^{5,17,21}$. Sodium hypochlorite $(\mathrm{NaOCl})$ and ethylenediaminetetraacetic acid 
(EDTA) are substances usually used during the endodontic treatment ${ }^{15,26,30}$. $\mathrm{NaOCl}$ is an auxiliary irrigant used during root canal instrumentation to promote debridement, lubrication, disinfection, tissue dissolution, collagen layer removal and dentin dehydration 7,8 . EDTA is indicated as a final irrigating agent that produces dentin demineralization and provides an excellent cleaning of the canal walls, improving the penetration of chemical substances and promoting a more intimate contact of the filling material with the radicular dentin ${ }^{14}$. EDTA acts on the inorganic components of the smear layer, leading to decalcification of the peri- and intertubular dentin. It also covalently binds to metal ions and sequesters calcium ions present in hydroxyapatite dentin ${ }^{4}$.

Endodontically treated teeth with a sufficient amount of sound coronary structure should preferably be restored with composite resin by the direct technique, due to its capacity to bond to dentin and increase the fracture resistance of the remaining dental structure ${ }^{11}$. This process requires appropriate interaction of the adhesive system with the dentin substrate ${ }^{29}$. However, the irrigating substances frequently used during the endodontic treatment could interfere in the bond strength of the composite resin to dentin ${ }^{21,32}$.

Studies evaluating the bond strength of dentin after the application of irrigating solutions present different methodology from the usual clinical protocol $16,22,23,27,28,34$ as regard concentration, presentation form (gel or liquid), and time that the solutions remain in root canal ${ }^{13}$, hence hindering appropriate comparisons with real clinical condition. These authors evaluated the influence of irrigating solutions on dentin bond strength after etching to verify the efficacy of a deproteinization technique.

In the present study, the irrigating solutions were placed in contact with the dentin for a longer period to simulate a restoration placed after completion of endodontic treatment. The microtensile bond strength ( $\mu$ TBS) of a self-etching adhesive system to dentin irrigated with $\mathrm{NaOCl}$ alone or combined with EDTA was evaluated, testing the null hypothesis that endodontic irrigants $(\mathrm{NaOCl}$ and EDTA) do not affect the bond strength of the self-etching adhesive system to dentin.

\section{MATERIAL AND METHODS}

\section{Experimental Design}

The factor under study was the irrigating solution at three levels: G1: No irrigating solution (control); G2: $1 \% \mathrm{NaOCl}$ (Natufarma Pharmacy, Passo Fundo, RS, Brazil); G3- $1 \% \mathrm{NaOCl}$ followed by the application of $17 \%$ EDTA (Biodynamics. Ibiporã, PR, Brazil). The restorative system was XENO III self-etching adhesive (Dentsply DeTrey; Konstanz,
Germany) and Z250 composite resin (3M ESPE, St Paul, MN, USA). The experimental units consisted of slabs of human dentin randomly distributed into the three experimental groups $(n=40)$. The response variable was $\mu$ TBS evaluated in $\mathrm{MPa}$.

\section{Selection of Teeth}

Thirty sound freshly-extracted human third molars were used in this study. Teeth were stored $0.5 \%$ chloramine solution at $4^{\circ} \mathrm{C}$ for 48 $\mathrm{h}$ for disinfection. Next, the teeth were cleaned with pumice/water slurry in Robinson brushes (Microdont, Socorro, SP, Brazil) and analyzed under x10 magnifying glass (Carl Zeiss, Jena, Germany). The teeth were stored in distilled water at $4^{\circ} \mathrm{C}$.

\section{uTBS Test}

Each tooth was individually included in PVC cylinder (25-mm diameter and 20-mm height) (Tigre, São Paulo, SP, Brazil) using colorless autopolymerizing acrylic resin (Jet Clássico, São Paulo, SP, Brazil), so that the occlusal surface faced upwards. The teeth were sectioned $3-\mathrm{mm}$ below the occlusal surface in a metallographic sectioning machine (Struers Minitom, Copenhagen, Denmark) and were polished (Struers Abramin, Copenhagen, Denmark) with silicon carbide papers (600- to 1200 -grit) of successively finer grits. The samples were washed for $60 \mathrm{~s}$ and stored in distilled water at $4^{\circ} \mathrm{C}$ for $24 \mathrm{~h}$.

The specimens were randomly distributed into the following groups: in group 1 (control), no irrigating solution was applied; in group 2, $1 \%$ $\mathrm{NaOCl}(5 \mathrm{~mL})$ was applied to the dentin surface every $5 \mathrm{~min}$ for $1 \mathrm{~h}$, simulating the time that $\mathrm{NaOCl}$-based irrigants are usually left in the root canals during endodontic treatment under clinical conditions; in Group 3, $1 \% \mathrm{NaOCl}$ was applied as described for Group 2, followed by a 5-min final rinse with $17 \%$ EDTA ( $5 \mathrm{~mL}$ ), simulating the duration of the final flush with this chelating agent during endodontic treatment under clinical conditions. After dentin treatments, all specimens were washed with distilled water for $60 \mathrm{~s}$.

In order to perform the adhesive technique in accordance with the manufacturer's instructions, the dentin received two layers of XENO III selfetching adhesive system using microbrush tips (Dentsply/DeTrey; Konstanz, Germany) followed by light curing for $20 \mathrm{~s}$ at $450 \mathrm{~mW} / \mathrm{cm}^{2}$ of light intensity (Radii device; SDI, São Paulo, SP, Brazil).

After hybridization, three increments ( $\sim 2 \mathrm{~mm}$ each) of Z250 composite resin (Shade A2) were applied on the dentin surface with a \#1/2 spatula, reaching a total height of $6 \mathrm{~mm}$. Each increment was light cured for $20 \mathrm{~s}$ with the Radii device.

After storage in distilled water for $24 \mathrm{~h}$, the specimens were placed in a metallographic sectioning 
machine (Struers Miniton; Copenhagen, Denmark) and a water-cooled double-faced diamond disk was used to cut sequential longitudinal 1.0-mm-thick sections in a mesiodistal direction. Care was taken not to separate the slices. The specimens were then removed from the acrylic resin base through a transversal section, to obtain resin/dentin slabs measuring approximately $10-\mathrm{mm}$ high, $5-\mathrm{mm}$ wide and $1-\mathrm{mm}$ thick. The slabs were trimmed on both sides of resin-dentin interface with a \#1093 FF bur (KG Sorensen; Barueri, SP, Brazil) at a high-speed handpiece (Kavo; Joinvile, SC, Brazil) to obtain a 1-mm thick central area and produce standard hourglass-shaped specimens (Figure 1 ).

The specimens were individually fixed in a metallic device with a cyanocrylate adhesive (Loctite Super Bonder; São Paulo, SP, Brazil) so that the resin/dentin interface remained without any contact for the microtensile test. The metallic device coupled

1

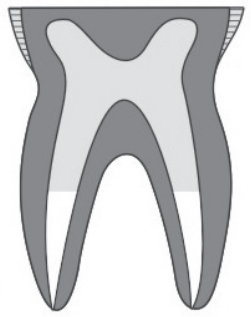

3

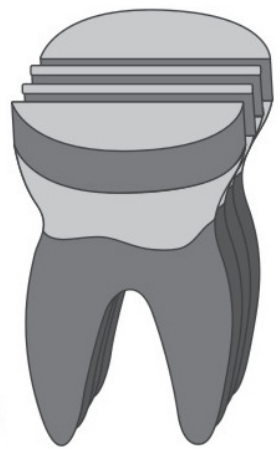

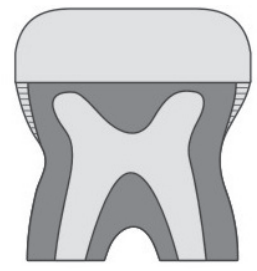

2

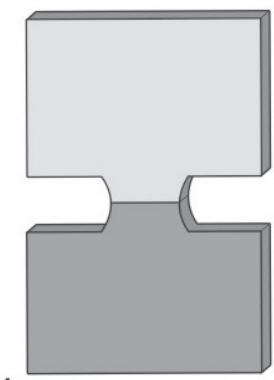

4

Figure 1-Schematic presentation of specimen preparation. (1) Exposed dentin, (2) Restored tooth, (3) Sectioning of the tooth to obtain four 1-mm-thick slabs from each tooth, (4) Hourglass-shaped specimen

Table 1- Microtensile bond strength ( $\mu$ TBS) means \pm standard deviations (MPa) of the self-etching adhesive system to coronal dentin after the different treatments

\begin{tabular}{cc}
\hline Irrigating solution & $\boldsymbol{\mu T B S}$ \\
\hline No irrigating solution (G1) & $11.89 \pm 4.22^{\mathrm{a}}$ \\
$1 \% \mathrm{NaOCl}(\mathrm{G} 2)$ & $19.41 \pm 5.32^{\mathrm{b}}$ \\
$1 \% \mathrm{NaOCl}+\mathrm{EDTA} \mathrm{17 \%} \mathrm{(G3)}$ & $11.34 \pm 4.73^{\mathrm{a}}$ \\
\hline
\end{tabular}

Different letters indicate statistically significant difference $(\alpha=0.001)$ to a universal testing machine (Emic DL 2000; São José of Pinhais, PR, Brazil) and the specimens were subjected to a microtensile strength at a crosshead speed of $0.5 \mathrm{~mm} / \mathrm{min}$ until fracture. At the moment of fracture, the resistance values were recorded in Newtons ( $\mathrm{N}$ ) by computer software.

Before the test, the area was measured with a digital caliper (Vonder Digital Electronic Paquímetro; Curitiba, PR, Brazil) and the bond strength was calculated in MPa using the following equation: $R t$ $=F / A$, where $R t$ is the $\mu$ TBS value, $F$ is the force applied and $A$ is the bond area between the dentin and restorative system. The data obtained were subjected to ANOVA and Newman Keuls tests $(\alpha=0.01)$.

\section{RESULTS}

Table 1 shows the mean $\mu$ TBS values and standard deviations (MPa) of the self-etching adhesive system to coronal dentin after the different treatments.

There was statistically significant difference between the irrigating solutions. The use of $1 \%$ $\mathrm{NaOCl}$ alone resulted in higher $\mu$ TBS of the selfetching adhesive system to dentin $(p<0.001)$ $F=22.5763$ ). There was no statistically significant difference between the use of $1 \% \mathrm{NaOCl}$ combined with $17 \%$ EDTA and the untreated control group (Table 1), confirming the hypothesis under study.

\section{DISCUSSION}

In the present study, the microtensile test was used due to the possibility of performing the analysis in an area of approximately $1.0-\mathrm{mm}^{14}$, producing uniformity in the stress distribution and contributing to obtaining accurate results ${ }^{18,20}$. The microtensile test can be accomplished through the analysis of non-trimmed sticks or hourglass-shaped samples $^{20}$. In this study, a small area was used to minimize potential defects and increase adhesion values $^{19}$

$\mathrm{NaOCl}$ is a halogenated compound, routinely used in Endodontics, which has low surface tension, antiseptic ability, partially neutralizes the toxic products of root canals and dissolves organic tissue ${ }^{2,14,24}$. However, it does not act on the inorganic portion of dentin, which constitutes great part of the smear layer ${ }^{9}$. EDTA, according to Zaccaro, et al. ${ }^{36}(2010)$, presents a softening effect on dentinal walls that helps the instrumentation of the canals and has proven efficiency in the removal of the smear layer. The association of both substances is largely used in endodontic therapy because they act in organic and inorganic portion of dentin at the same time, hence making the instrumentation process more efficient $t^{6,30,37}$. 
Considering that the adhesion of restorative materials to dentin of endodontically treated teeth can be altered ${ }^{27}$ when using irrigating solutions as $\mathrm{NaOCl}^{32}$ and EDTA followed by the application of the adhesive system ${ }^{21}$, and that higher adhesion values can be obtained using adhesive systems in dentin not previously treated by the irrigating solutions $\mathrm{s}^{35}$, this study investigated whether self-etching adhesive system could also favor an increase in bond strength to dentin.

The outcomes of the present study revealed that irrigation with $1 \% \mathrm{NaOCl}$ during $1 \mathrm{~h}$ (reapplied every $5 \mathrm{~min}$ ) yielded higher $\mu$ TBS of XENO III selfetching system to dentin. A probable explanation for this fact is the superficial morphology of dentin treated with $\mathrm{NaOCl}$, which does not remove the smear layer and expose the dentinal tubules ${ }^{9}$. The self-etching adhesive system has modified phosphoric acid on its composition (with high initial acidity) that incorporates the smear layer available on surface and forms the hybrid layer, increasing the bond resistance. Another factor that could justify the higher adhesion results can be related to the residual presence of water in the adhesive interface ${ }^{25}$.

Some studies showed that $\mathrm{NaOCl}$ affects the bond strength of adhesive materials to dentin, however, they present different methodologies from that used on this study, as regarding concentration, immersion time and presentation form of the irrigating solutions $\mathrm{s}^{13,16,27,34}$, hindering appropriate comparison with the obtained results.

Ozturk and Özer ${ }^{17}$ (2004) compared the effect of $5 \% \mathrm{NaOCl}$ on bond strength of of Clearfil SE Bond, Prompt L Pop, Scotchbond Multi Purpose and Prime Bond NT to pulp chamber lateral walls and verified significant decrease for all tested systems. Santos, et al. ${ }^{22}$ (2005) also observed a decrease in the bond strength of Single Bond after the deproteinization technique with $\mathrm{NaOCl}$. Sauro, et al. ${ }^{23}$ (2009) found higher bond strength when $\mathrm{NaOCl}$ was applied on dentin after the acid conditioning and the authors emphasized that this technique may result in more durable resin-dentin bonds.

The application of the self-etching adhesive system promoted similar bond strength between the control group (no irrigating solution) and the group irrigated with $1 \% \mathrm{NaOCl}$ followed by $17 \%$ EDTA, suggesting that the erosion in dentin surface caused by EDTA ${ }^{4,10}$ did not affect the formation of dentinresin bonds. Santos, et al. ${ }^{21}$ (2006) obtained lower bond strength values for a self-etching adhesive system when $5.25 \% \mathrm{NaOCl}$ was used combined with $17 \%$ EDTA than the application of $\mathrm{NaOCl}$ alone on dentin.

Regarding the positive results of the self-etching adhesive system after treatment of dentin surface with irrigating solutions, further research should investigate the degradation of the adhesive/dentin interface formed with these systems after surface treatment with different root canal irrigants.

\section{CONCLUSION}

Based on the obtained results and according to the employed methodology, it may be concluded that none of the endodontic irrigants affected negatively the $\mu$ TBS of XENO III self-etching adhesive system to dentin. While the use of $1 \%$ $\mathrm{NaOCl}$ alone resulted in higher bond strength than the other treatments, the combination of $1 \% \mathrm{NaOCl}$ and $17 \%$ EDTA produced similar bond strength to that of untreated dentin.

\section{REFERENCES}

1- Ausiello P, De Gee AJ, Rengo S, Davidson CL. Fracture resistance of endodontically-treated premolars adhesively restores. Am J Dent. 1997;10(5):237-41.

2- Baumgartner JC, Mader CL. A scanning electron microscopic evaluation of four root canal irrigation regimens. J Endod. 1987;13(4):147-57.

3- Belli S, Zhang Yi, Pereira PNR, Ozer F, Pashley DH. Regional bond strengths of adhesive resins to pulp chamber dentin. J Endod. $2001 ; 27(8): 527-32$

4- Calt S, Serper A. Smear layer removal by EGTA. J Endod $2000 ; 26(8): 459-61$.

5- Campos EA, Correr GM, Leonardi DP, Barato-Filho F, Gonzaga CC, Zielak JC. Chlorhexidine diminishes the loss of bond strength over time under simulated pulpal pressure and thermo-mechanical stressing. J Dent. 2009;37(2):108-14.

6- Cengiz T, Aktener BO, Piskin B. The effect of dentinal tubule orientation of the removal of the smear layer by root canal irrigation. A scanning electron microscopic study. Int Endod J. $1999 ; 23(3): 163-71$.

7- Estrela C, Estrela CR, Barbin EL, Spanó JC, Machesan MA, Pécora JD. Mechanism of action of sodium hypochlorite. Braz Dent J. $2002 ; 13(2): 113-7$.

8- Estrela C, Estrela CR, Decurcio DA, Hollanda AC, Silva JA. Antimicrobial efficacy of ozonated water, gaseous ozone, sodium hypochlorite and chlorhexidine in infected human root canals. Int Endod J. 2007;40(2):85-93.

9- Garberolio R, Becce C. Smear layer removal by root canal irrigants. A comparative scanning electron microscopic study. Oral Surg Oral Med Oral Pathol. 1994;78(3):359-67.

10- Hayashi M, Takahashi Y, Hirai M, Iwami Y, Imazato S, Ebisu $S$. Effect of endodontic irrigation on bonding of resin cement to radicular dentin. Eur J Oral Sci. 2005;113(1);70-6.

11- Hernandez R, Bader S, Boston D, Trope M. Resistance to fracture of endodontically treated premolars restored with new generation dentine bonding systems. Int Endod J. $1994 ; 27(2): 281-4$.

12- Hommez GM, Coppens CR, De Moor RJ. Periapical health related to the quality of coronal restorations and root fillings. Int Endod J. 2002;35(8):680-9.

13- Inoue $\mathrm{S}$, Murata $\mathrm{Y}$, Sano $\mathrm{H}$, Kashiwada T. Effect of $\mathrm{NaOCl}$ treatment on bond strength between indirect resin core-buildup and dentin. Dent Mater J. 2002;21(4):343-54.

14- Johal S, Baumgartner JC, Marshall JG. Comparison of the antimicrobial efficacy of $1.3 \% \mathrm{NaOCl}$ /BioPure MTAD to $5.25 \% \mathrm{NaOCl} / 15 \%$ EDTA for root canal irrigation. J Endod. $2007 ; 33(1): 48-51$. 
15- Keleş A, Köseoğlu M. Dissolution of root canal sealers in EDTA and $\mathrm{NaOCl}$ solutions. J Am Dent Assoc. 2009;140(1):74-9. 16- Miyasaka K, Nakabayashi N. Combination of EDTA conditioner and Phenyl-P/HEMA self-etching primer for bonding to dentin. Dent Mater. 1999;15(3):153-7.

17- Ozturk B, Özer F. Effect of $\mathrm{NaOCl}$ on bond strength of bonding agents to pulp chamber lateral walls. J Endod. 2004;30(5):362-5. 18- Pashley DH, Sano H, Ciucchi B, Yoshiyama M, Carvalho RM. Adhesion testing of dentin bonding agents: a review. Dent Mater. 1995; 11(2):117-25.

19- Phrukkanon S, Burrow MF, Tyas MJ. The influence of crosssectional shape and surface area on the microtensile bond test. Dent Mater. 1998;14(3):212-21.

20- Sano H, Shono T, Sonoda H, Takatsu T, Ciucchi B, Carvalho R, et al. Relationship between surface area for adhesion and tensile bond strength - evaluation of a micro-tensile bond test. Dent Mater. 1994;10(4):236-40.

21- Santos JN, Carrilho MR, De Goes MF, Zaia AA, Gomes BP, Souza-Filho FJ, et al. Effect of chemical irrigants on the bond strength of a self-etching adhesive to pulp chamber dentin. J Endod. 2006;32(11):1088-90.

22- Santos PH, Sinhoreti MA, Consani S, Sobrinho LC, Adabo GL, Vaz LG. Effect of cyclic compressive loading on the bond strength of an adhesive system to dentin after collagen removal. J Adhes Dent. $2005 ; 7(2): 127-31$.

23- Sauro S, Mannocci F, Toledano M, Osorio R, Pashley DH, Watson TF. EDTA or $\mathrm{H} 3 \mathrm{PO} 4 / \mathrm{NaOCl}$ dentine treatments may increase hybrid layers resistance to degradation a microtensile bond strength and confocal-micropermeability study. J Dent. 2009;37(4):279-88.

24- Sayin TC, Cehreli ZC, Deniz D, Akcay A, Tuncel B, Dagli F, et al. Time-dependent decalcifying effects of endodontic irrigants with antibacterial properties. J Endod. 2009;35(2):280-3.

25- Tay FR, Pashley DH, Suh BI, Carvalho RM, Itthagarun A. Single-step adhesives are permeable membranes. J Dent. 2002;30(7-8):371-82.

26- Teixeira CS, Felippe MC, Felippe WT. The effect of application time of EDTA and $\mathrm{NaOCl}$ on intracanal smear layer removal: an SEM analysis. Int Endod J. 2005;38(5):285-90.
27- Turkün M, Turkün LS, Kalender A. Effect of cavity disinfectants on the sealing ability of nonrinsing dentin-bonding resins. Quintessense Int. 2004;35(6):469-76.

28- Uceda-Gómez N, Loguercio AD, Moura SK, Grande RH, Oda $M$, Reis $A$. Long-term bond strength of adhesive systems applied to etched and deproteinized dentin. J Appl Oral Sci. 2007;15(6):475-9.

29- Vargas MA, Cobb DS, Amstrong SR. Resin-dentin shear bond strength and interfacial ultrastructure with and without a hybrid layer. Oper Dent. 1997;22(4):159-66.

30- Vasconcelos BC, Luna-Cruz SM, De-Deus G, Moraes IG, Maniglia-Ferreira C, Gurgel-Filho ED. Cleaning ability of chlorhexidine gel and sodium hypochlorite associated or not with EDTA as root canal irrigants: a scanning electron microscopy study. J Appl Oral Sci. 2007;15(5):387-91.

31- Vire DE. Failure of endodontically treated teeth: classification and evaluation. J Endod. 1991;17(7):338-42.

32- Vongphan N, Senawongse P, Somsiri W, Harnirattisai C. Effects of sodium ascorbate on microtensile bond strength of total-etching adhesive system to $\mathrm{NaOCl}$ treated dentine. J Dent. 2005;33(8):689-95.

33- Wachlarowicz AJ, Joyce AP, Roberts S, Pashley DH. Effect of endodontic irrigants on the shear bond strength of epiphany sealer to dentin. J Endod. 2007;33(2):152-5.

34- Yamauti M, Hashimoto M, Sano $H$, Ohno $H$, Carvalho RM, Kaga $\mathrm{M}$, et al. Degradation of resin-dentin bonds using $\mathrm{NaOCl}$ storage. Dent Mater. 2003;19(5):399-405.

35- Yeşilyurt C, Bulucu B. Bond strength of total-etch and selfetch dentin adhesive systems on peripheral and central dentinal tissue: a microtensile bond strength test. J Contemp Dent Pract. 2006;7(2):26-36.

36- Zaccaro SMF, Silva PVS, Chagas MA, Silva LE, Scelza P. Evaluation of inflammatory response of EDTA, EDTA-T, and citric acid in animal model. J Endod. 2010;36(3):515-9.

37- Zhang K, Kim YK, Cadenaro M, Bryan TE, Sidow SJ, Loushine RJ, et al. Effects of different exposure times and concentrations of sodium hypochlorite/ethylenediaminetetraacetic acid on the structural integrity of mineralized dentin. J Endod. 2010;36(1):105-9. 